\title{
A Study on Engineering Behavior of Black Cotton Soil and its Stabilization by Use of Lime
}

\author{
Brajesh Mishra \\ M. Tech., Assistant Engineer, U.P. Cane Development Department, Lucknow, India
}

\begin{abstract}
With rapid growth of population, fast urbanization and more construction of buildings and other structures has resulted in reduction of good quality available land. There is no choice for People except to use soft and weak soils around for construction activities. Such soil possesses poor shear strength and high swelling \& shrinkage. The mechanical behavior of such nature of soil has to be improved by employing stabilization and reinforcement techniques to make it reliable for construction activities. Black cotton soil is one of the major issues in India. When exposed to variation in moisture content they undergo high swelling and shrinkage making it more complicated for engineering point of view. Lime is added to black cotton soil and stabilization takes place by virtue of pozzolanic reaction. A reaction takes place between hydrated lime and clay particles and resulting in formation of permanent strong cementation matrix. Experimental work has been carried out with 3\% and 5\% of lime content. Samples of black cotton soil were collected from Jhansi a district in state of Uttar Pradesh in India The basic properties of soil were determined. Changes in various soil properties like Liquid limit, Plastic Limit, California Bearing Ratio(CBR) and Maximum Dry Density were analyzed.
\end{abstract}

Keywords: Density, lime, black cotton soil, stabilization, California Bearing Ratio(CBR).

\section{Introduction}

Black cotton soil are found in extensive region of Deccan Trap in Indian. They are of variable thickness, underlain by black sticky material known as "black soil". Black cotton soil when comes in contact with water it either swells or shrinks and resulting in moments to the structure which are generally not related to direct effect of loading. On account of its high volumetric changes it is not suitable for construction. It swells and shrinks excessively due to present of fine clay particles. Alternate swelling and shrinking of soil is responsible for differential settlement of structure so black cotton soil must be treated by using suitable admixtures to stabilize it. In my research work stabilization of black cotton soil is done by using lime as an admixture. Experimental work has been carried out with $3 \%$ and $5 \%$ of lime content.

The most common type of stabilization are listed below-

- Lime stabilization

- Cement stabilization

- Chemical stabilization

- Bitumen stabilization

- Salt stabilization

\section{Literature Review}

\subsection{Black cotton soil in India}

Almost 20\% area of is occupied by black cotton soil. These soil are predominant in states of Andhra Pradesh, Western Madhya Pradesh, Gujrat, Maharashtra, Northern Karnataka, Tamil Nadu and some parts of Southern Uttar Pradesh (Bundelkhand area). They are mostly clay soils and form deep cracks during dry season. They are popularly known as "Black Cotton Soils" because of their dark brown color and suitability for growing cotton. They are black due to compounds of iron and aluminum. These soils are deficient in nitrogen, phosphoric acid and organic matter but rich in calcium potash and magnesium.

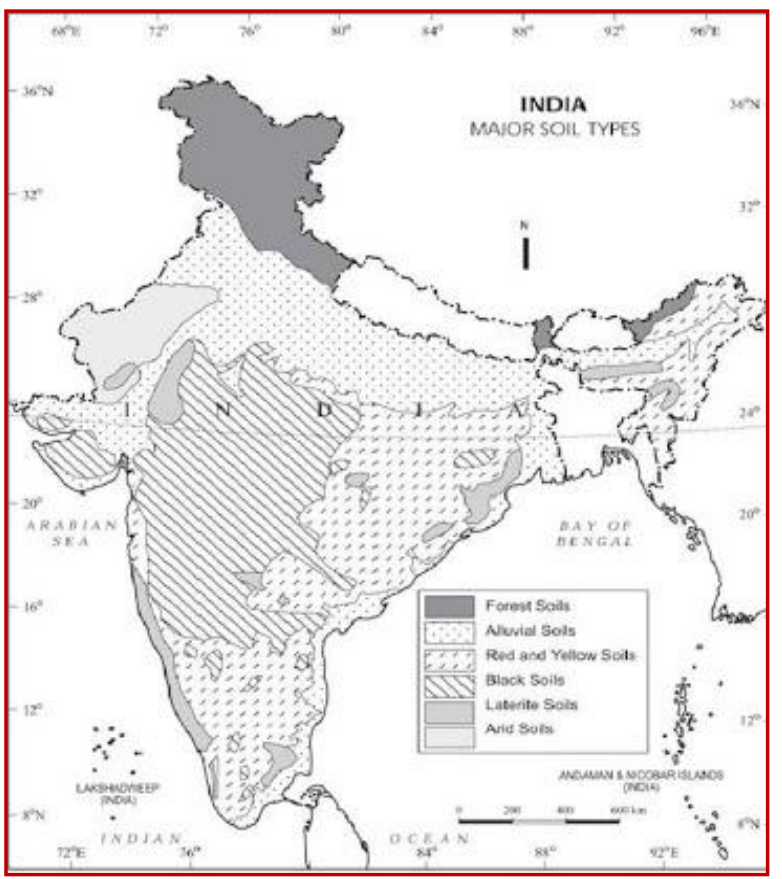

Figure 1: Map of India showing Black Cotton \& other soils

\subsection{Characteristics of Black cotton soil}

Black cotton soil are generally reddish brown to black in color. They occur $0.50 \mathrm{~m}$ to $10 \mathrm{~m}$ deep possessing high compressibility. Common characteristics are listed in table-1 below- 


\section{International Journal of Science and Research (IJSR) \\ ISSN (Online): 2319-7064}

Index Copernicus Value (2013): 6.14 | Impact Factor (2014): 5.611

Table 1: Characteristics of Black cotton soil

\begin{tabular}{|c|l|c|}
\hline S. No. & \multicolumn{1}{|c|}{ Property } & Value \\
\hline 1 & Dry density $(\gamma d)$ & $1300-1800 \mathrm{Kg} / \mathrm{m}^{3}$ \\
\hline 2 & Liquid Limit (L.L.) & $40-120 \%$ \\
\hline 3 & Plastic Limit (P.L.) & $20-60 \%$ \\
\hline 4 & Activity & $0.8-18 \%$ \\
\hline 5 & Specific Gravity(G) & $2.60-2.75$ \\
\hline 6 & Proctor Density & $1350-1600 \mathrm{Kg} / \mathrm{m}^{3}$ \\
\hline 7 & OMC ( Max dry density) & $20-35 \%$ \\
\hline 8 & Free Swell Index & $40-180 \%$ \\
\hline 9 & Swelling pressure & $50-800 \mathrm{KN} / \mathrm{m}^{2}$ \\
\hline 10 & C.B.R. (soaked) & $1.2-4.0$ \\
\hline 11 & Compression Index & $0.2-0.5$ \\
\hline 12 & Fines $(<75 \mu)$ & $70-100 \%$ \\
\hline 13 & $2 \mu$ Fraction & $20-60 \%$ \\
\hline 14 & Soil Classification & $\mathrm{CH}$ or $\mathrm{MH}$ \\
\hline
\end{tabular}

\subsection{Chemical composition of Black cotton soil}

Chemical compositions of black cotton soil are listed in table-2 below-

Table 2: Chemical compositions of black cotton soil

\begin{tabular}{|c|c|c|}
\hline S. No. & Property & Value \\
\hline 1 & $\mathrm{pH}$ value & $>7$ (Alkaline) \\
\hline 2 & Organic Content & $0.4-204 \%$ \\
\hline 3 & $\mathrm{CaCO} 3$ & $1-15 \%$ \\
\hline 4 & $\mathrm{SiO} 2$ & $50-55 \%$ \\
\hline 5 & $\mathrm{SiO} 2, \mathrm{Al} 2 \mathrm{O} 3$ & $3-5 \%$ \\
\hline 6 & Montmorrilonite Mineral & $30-50 \%$ \\
\hline
\end{tabular}

Black cotton soil consists of clay minerals like Montmorrilonite, Illite and Kaolinite, chemicals like iron oxide and calcium carbonate (in the form of kankars), and organic matter like humus. Montmorrilonite is the predominant mineral of Black cotton soils. The swelling and shrinkage behavior of black cotton soil originate mainly from this mineral are hydrous silicates of aluminum and magnesium .They are made of sheets of silica (tetrahedral) and alumina (octahedral) stacked on above the other forming sheet like of flaky particle. Montmorrilonite has a three sheeted structure with expanding lattices. The structure carries negative charge, due to isomorphic substitution of some aluminum ions by magnesium ions and minerals becomes chemically active.

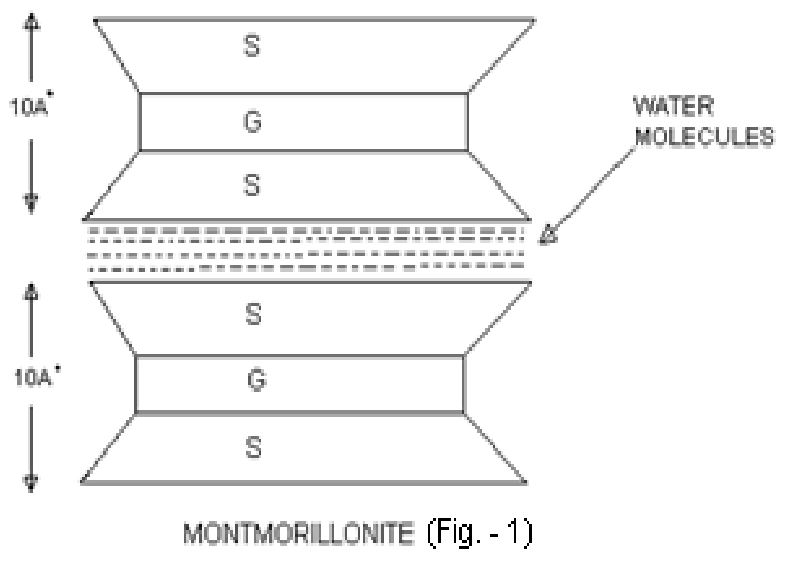

Figure 2: Structure of Montmorrilonite Mineral

\subsection{Problem Associated with B. C. Soil}

Due to their peculiar nature Black Cotton soils are challenge for engineers everywhere in the world, and more so in tropical countries like India because of wide variation in temperature and because of distinct dry and wet seasons, leading to wide variations in moisture content of soils. The following problems generally occur in black cotton soil -

High Compressibility: Black Cotton soils are highly plastic and compressible, when they are saturated. Footing, resting on such soils under goes consolidation settlements of high magnitude.

Swelling: A structure built in a dry season, when the natural water content is low shows differential movement as result of soils during subsequent wet season. This causes structures supported by such swelling soils to lift up and crack. Restriction on having developed swelling pressures making the structure suitable.

Shrinkage: A structure built at the end of the wet season when the natural water content is high, shows settlement and shrinkage cracks during subsequent dry season.

2.5.Engineering Properties of B. C. Soil The main engineering properties of soil are permeability, plasticity, compaction, compressibility and shear strength.

Permeability: The permeability is defined as the property of a porous material which permits the passage or seepage of water through its interconnecting voids

Plasticity: It is defined as the property of a soil which allows it to be deformed rapidly, without elastic rebound, without volume change.

Compaction: Compaction is a process by which the soil particles artificially rearrange and packed together into a closer state of contact by mechanical means in order to decrease the porosity of the soil and thus increase its dry density.

Compressibility: The property of soil mass pertaining to its susceptibility to decrease in volume under pressure is known as compressibility.

Shear Strength: This is the resistance to deformation by continuous shear displacement of soil particles or on masses upon the action of a shear stress.

\subsection{Index Properties of B. C. Soil}

The properties of soil, which are not of primary interest to the geotechnical engineering, but are indicative of the engineering properties are called index properties. This includes -

Particle Size Analysis: This is method of separation soils into different fraction bases on particles present into soils. It can be shown graphically on a particle size distribution curve. 


\section{International Journal of Science and Research (IJSR) \\ ISSN (Online): 2319-7064 \\ Index Copernicus Value (2013): 6.14 | Impact Factor (2014): 5.611}

Specific Gravity: It can be classified as the ratio of the weights of a given volume of soil solid at a given temperatures of the weight of an equal volume of distilled water at that temperature both weight being taken in air.

The range of specific gravity of coal ashes varies from 1.46 to 2.66 the low values of specific gravity is because of hollow particles chemosphere the sp. Gr. Of soil solids is determined by -

1. $50 \mathrm{ml}$ density bottle or

2. A $500 \mathrm{ml}$ flask or

3. A pycnometer

The density bottle method is most accurate and is suitable for all types of soil the flask or pycnometer method is suitable for coarse grained soil.

Atterberg's Limit: The water content at which the soil changes from one state to other state are known as consistency limits or Atterbergees limit .The Atterbergees limit which are useful for engineering purposes are; Liquid limit, plastic limit and shrinkage limit. These limits are expressed as percent water content.

Liquid limit: - It is defined as the minimum water content at which the soil is still in liquid state but has a small strength against flowing which can be measured by standard available means.

Plastic limit:- It is defined as minimum water content at which soil will just begin to crumble water rolled into a thread approximately $3 \mathrm{~mm}$ in diameter, Plasticity index is determined as difference of L.L. and P.L.

Shrinkage limit: - It is defined as the maximum water content at which a reduction in water content will not cause a decrease in the volume of soil mass.

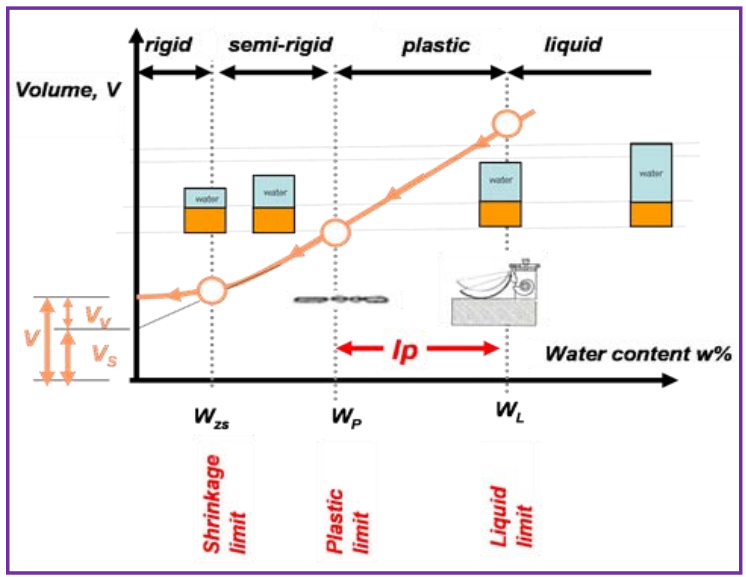

Figure 3: Interpretation of Consistency limits

\section{Lime Stabilization}

Lime stabilization helps in increasing the strength, durability and also minimizes the moisture variations in the soil and lime must be well compacted for obtaining sufficient strength and durability by maintaining OMC and the same assumption is made in the experimental determination of the required lime proportion. Quality of lime to be added depends upon the specific surface area of soil particles and it is more for fine grained soils even up to $15 \%$ by weight of soil. The prime benefit of using lime to stabilize clays are increased strength, improved workability and volume stability. Workability is increased because flocculation makes the clay more friable, this assists combination for effective mixing and compaction. Lime increases the optimum water content for compaction, which is a advantage when dealing with a wet soil. Lime increases the strength of soil resulting in improvement in durability to traffic load and resistance to water, wind and freeze-thaw cycles. The stabilization of black cotton soil with lime has been done in three different ratios of lime i.e. $0 \%, 3 \%$ and $5 \%$. After the stabilization of soil with lime in above percentage the various tests were performed -

Liquid Limit Tests: The liquid limit of a soil is the moisture content, expressed as a percentage of the weight of the ovendried soil, at the boundary between the liquid and plastic states of consistency. The moisture content at this boundary is arbitrarily defined as the water content at which two halves of a soil cake will flow together, for a distance of $1 / 2$ in. $(12.7 \mathrm{~mm})$ along the bottom of a groove of standard dimensions separating the two halves, when the cup of a standard liquid limit apparatus is dropped 25 times from a height of $0.3937 \mathrm{in} .(10 \mathrm{~mm})$ at the rate of two drops/second.
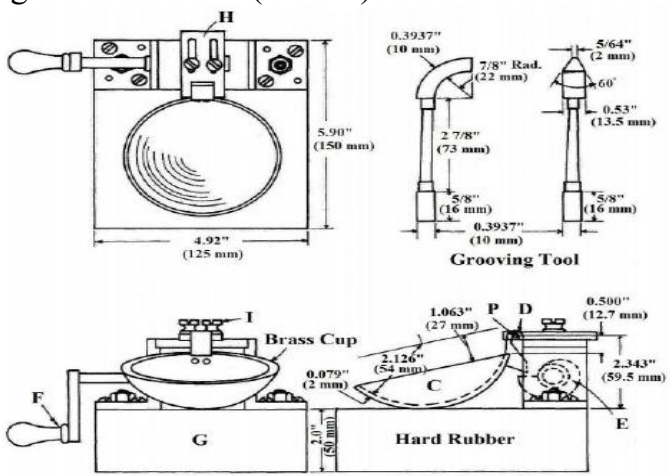

Figure 4: Mechanical Liquid Limit Device

\section{Plastic Limit Tests}

The plastic limit of a soil is the moisture content, expressed as a percentage of the weight of the oven-dry soil, at the boundary between the plastic and semisolid states of consistency. It is the moisture content at which a soil will just begin to crumble when rolled into a thread $1 / 8$ in. $(3 \mathrm{~mm})$ in diameter using a ground glass plate or other acceptable surface.

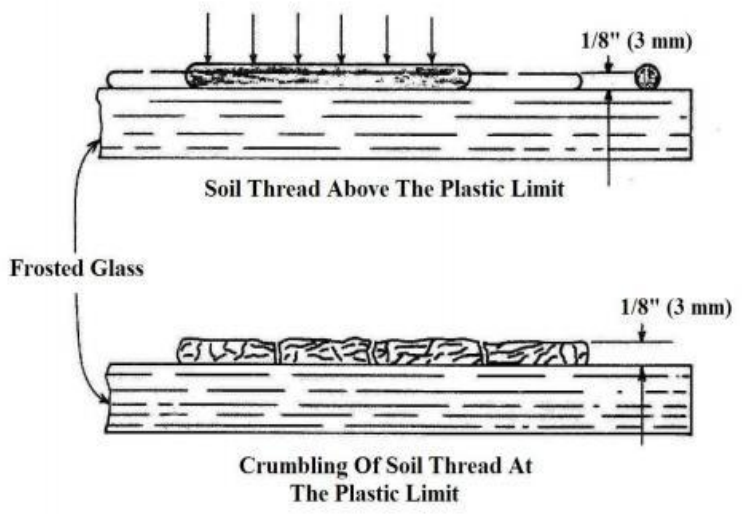

Figure 5: Diagrams Illustrating Plastic Limit Test

\section{Volume 4 Issue 11, November 2015}




\section{International Journal of Science and Research (IJSR) \\ ISSN (Online): 2319-7064 \\ Index Copernicus Value (2013): 6.14 | Impact Factor (2014): 5.611}

\section{Plasticity Index}

The plasticity index of a soil is the numerical difference between its liquid limit and its plastic limit, and is a dimensionless number. Both the liquid and plastic limits are moisture contents.

\section{Calculation:}

Plasticity Index $=$ Liquid Limit - Plastic Limit $\mathrm{PI}=\mathrm{LL}-\mathrm{PL}(2)$

\section{Compaction Test}

Compaction is one kind of densification that is realized by rearrangement of soil particles without outflow of water. It is realized by application of mechanic energy. It does not involve fluid flow, but with moisture changing altering.

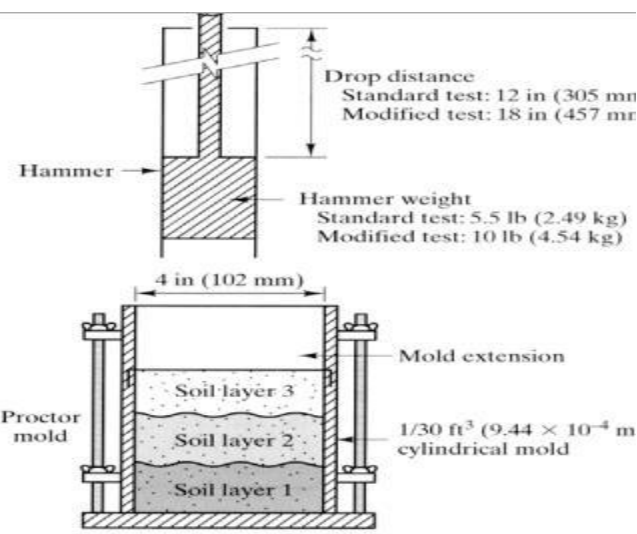

Figure 6: Standard Proctor Apparatus for Compaction Test

\section{California Bearing Ratio (C.B.R.) Test}

California bearing ratio is the ratio of force per unit area required to penetrate in to a soil mass with a circular plunger of $50 \mathrm{~mm}$ diameter at the rate of $1.25 \mathrm{~mm} / \mathrm{min}$.

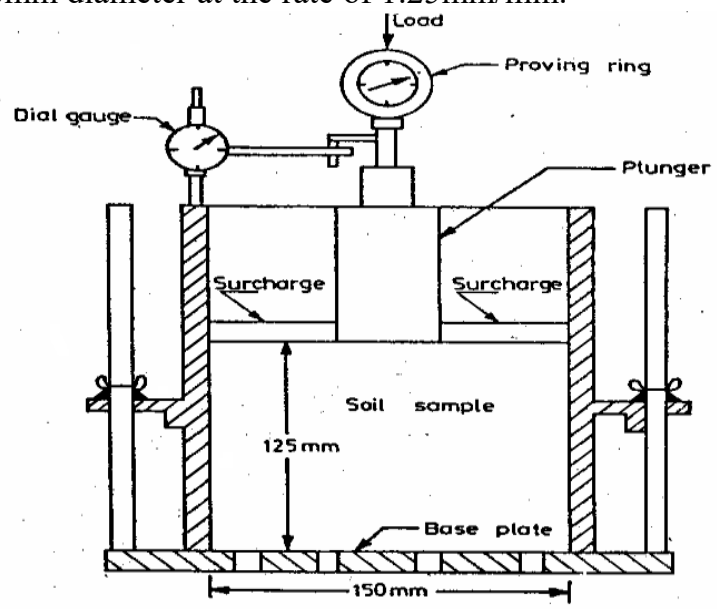

Figure 7: California Bearing Ratio Apparatus

\section{Results of Experimental Investigations}

The results of the following tests are as follows -

Liquid Limit Test: Weight of sample taken $=100$ grams
Table-3- Comparison of Liquid Limit

\begin{tabular}{|c|c|c|c|c|c|c|}
\hline S.No. & \multicolumn{2}{|c|}{$\begin{array}{c}\text { Black Cotton } \\
\text { soil+0\% Lime }\end{array}$} & \multicolumn{2}{c|}{$\begin{array}{c}\text { Black Cotton } \\
\text { soil+3\% Lime }\end{array}$} & \multicolumn{2}{c|}{$\begin{array}{c}\text { Black Cotton } \\
\text { soil+5\% Lime }\end{array}$} \\
\cline { 2 - 7 } & $\begin{array}{c}\% \text { of } \\
\text { water }\end{array}$ & $\begin{array}{c}\text { No. of } \\
\text { blows }\end{array}$ & $\begin{array}{c}\% \text { of } \\
\text { water }\end{array}$ & $\begin{array}{c}\text { No. of } \\
\text { blows }\end{array}$ & $\begin{array}{c}\% \text { of } \\
\text { water }\end{array}$ & $\begin{array}{c}\text { No. of } \\
\text { blows }\end{array}$ \\
\hline 1 & 42 & 58 & 41 & 28 & 34 & 38 \\
\hline 2 & 44 & 28 & 43 & 17 & 36 & 32 \\
\hline 3 & 46 & 16 & 45 & 11 & 38 & 16 \\
\hline 4 & \multicolumn{3}{|c|}{$\begin{array}{c}\text { Liquid Limit } \\
\text { (L.L.) }=44.40\end{array}$} & \multicolumn{2}{c|}{$\begin{array}{c}\text { Liquid Limit } \\
\text { (L.L.) }=43.20\end{array}$} & \multicolumn{2}{c}{$\begin{array}{c}\text { Liquid Limit } \\
\text { (L.L.) }=36.40\end{array}$} \\
\hline
\end{tabular}

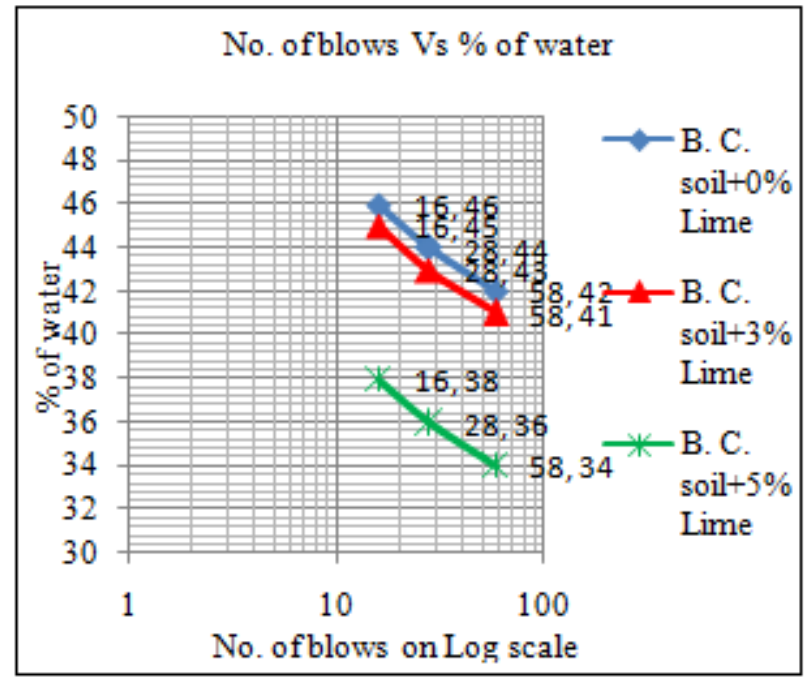

Figure 8: Comparison of Liquid Limit

Plastic Limit Test: Weight of sample taken $=100$ grams

Table 4: Comparison of Plastic Limit

\begin{tabular}{|c|c|c|}
\hline S. No. & Composition of soil & Plastic Limit \\
\hline 1 & Black Cotton soil+0\% Lime & $30 \%$ \\
\hline 2 & Black Cotton soil $+3 \%$ Lime & Non- Plastic \\
\hline 3 & Black Cotton soil+5\% Lime & Non- Plastic \\
\hline
\end{tabular}

Plasticity Index:

Table 5: Plasticity Index

\begin{tabular}{|c|c|c|}
\hline S. No. & Composition of soil & $\begin{array}{c}\text { Plasticity Index (P.I.) } \\
\text { P.I. = L.L.- P.L. }\end{array}$ \\
\hline 1 & Black Cotton soil+0\% Lime & $14.40 \%$ \\
\hline 2 & Black Cotton soil+3\% Lime & - \\
\hline 3 & Black Cotton soil+5\% Lime & - \\
\hline
\end{tabular}

Compaction Test: This test was performed to determine the compaction parameters of soil.

Weight of sample $=3000$ grams

Mass of mould $(\mathrm{W} 1)=5510$ grams

Volume of mould $(\mathrm{v})=1000$ c.c.

Table 6: Compaction test comparison of different compositions of B.C. soil

\begin{tabular}{|c|c|c|c|c|}
\hline S. No. & Descriptions & $\begin{array}{c}\text { Black } \\
\text { Cotton } \\
\text { soil+0\% } \\
\text { Lime }\end{array}$ & $\begin{array}{c}\text { Black } \\
\text { Cotton } \\
\text { soil+3\% } \\
\text { Lime }\end{array}$ & $\begin{array}{c}\text { Black } \\
\text { Cotton } \\
\text { soil+5\% } \\
\text { Lime }\end{array}$ \\
\hline 1 & $\begin{array}{c}\text { Mass of mould + compacted } \\
\text { soil (W2) grams }\end{array}$ & 7150 & 7256 & 7215 \\
\hline 2 & $\begin{array}{c}\text { Mass of compacted soil } \\
\text { (grams) W3 }=\mathrm{W} 2-\mathrm{W} 1\end{array}$ & 1640 & 1746 & 1705 \\
\hline 3 & $\begin{array}{c}\text { Wet density } \gamma \mathrm{b}=\mathrm{W} 3 / \mathrm{v} \\
\left.\text { (grams } / \mathrm{cm}^{3}\right)\end{array}$ & 1.64 & 1.75 & 1.70 \\
\hline 4 & Moisture content, $\mathrm{W}(\%)$ & 14.5 & 14.5 & 12.5 \\
\hline 5 & $\begin{array}{c}\text { Dry density } \gamma \mathrm{d}=[\gamma \mathrm{b} / 1+\mathrm{w}] \\
\text { grams } / \mathrm{cm}^{3}\end{array}$ & 1.43 & 1.52 & 1.51 \\
\hline
\end{tabular}




\section{International Journal of Science and Research (IJSR) \\ ISSN (Online): 2319-7064}

Index Copernicus Value (2013): 6.14 | Impact Factor (2014): 5.611

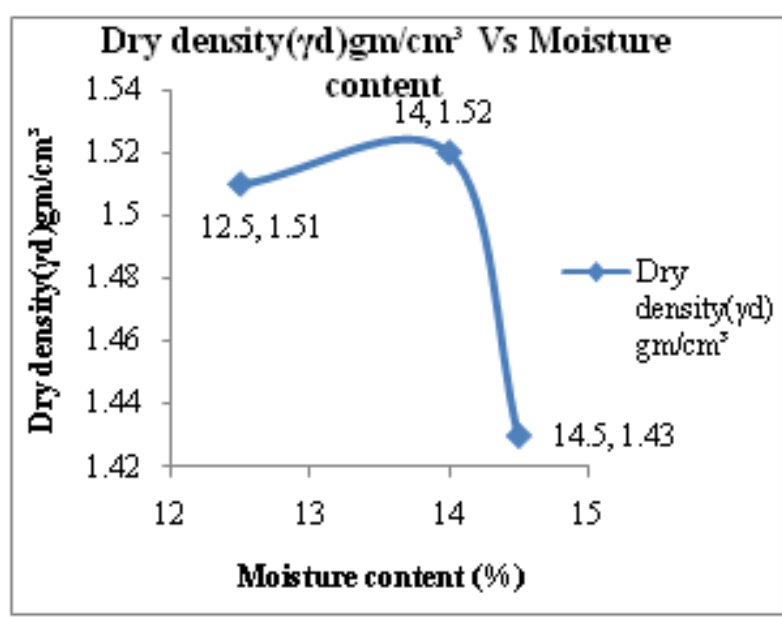

Figure 9: Dry density $(\gamma \mathrm{d}) \mathrm{gm} / \mathrm{cm}^{3}$ Vs Moisture content

California Bearing Ratio (C.B.R.)Test: Comparison of C.B.R. values of different composition of B.C. soil is tabled below-

Table 7: C.B.R. test comparison of different compositions of B.C. soil

\begin{tabular}{|c|c|c|}
\hline S. No. & Composition of soil & C.B.R. value \\
\hline 1 & Black Cotton soil+0\% Lime & 2.0 \\
\hline 2 & Black Cotton soil $+3 \%$ Lime & 6.50 \\
\hline 3 & Black Cotton soil $+5 \%$ Lime & 9.52 \\
\hline
\end{tabular}

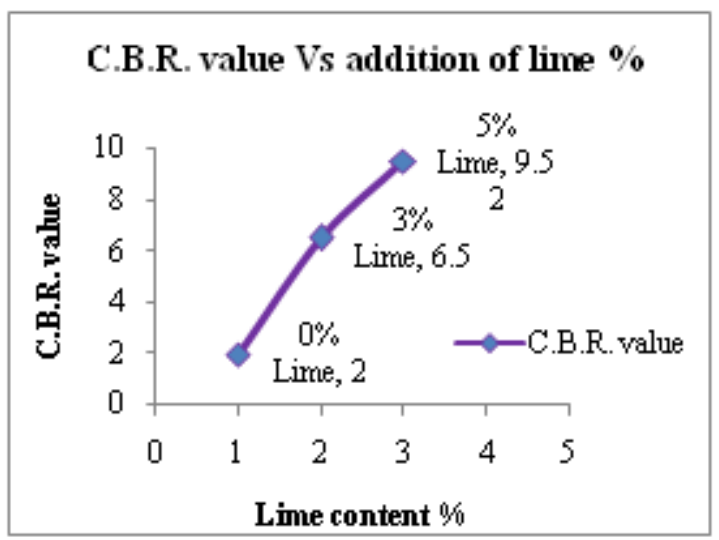

Figure 10: C.B.R. value at different lime percentage

\section{Conclusions}

On the basis of study and experimental investigations it was observed that the property of black cotton soil effectively improved by use of different percentage of lime contents. In this research varying percentage ( $3 \%$ and $5 \%$ ) of lime was used to stabilize the black cotton soil. Points which were drawn from this study are listed below-

- It was observed that on addition of $3 \%$ of lime decreases the liquid limit by $2.70 \%$ while with $5 \%$ addition of lime reflects a decrease $15.27 \%$.

- M.D.D. was increased slightly by $6.29 \%$ and $5.59 \%$ at $3 \%$ and 5\% lime content respectively.

- It was observed that there was a decrease in O.M.C. of $3.4 \%$ and $10.7 \%$ at $3 \%$ and at $5 \%$ lime content. respectively.

- The C.B.R. value of black cotton soil improve considerably to 3.25 times and 4.76 times with $3 \%$ and $5 \%$ lime respectively.
- There was a decrease in swelling pressure by $28 \%$ and by $55 \%$ in Black cotton soil with $3 \%$ and $5 \%$ lime respectively.

\section{References}

[1] A Study on Some Geotechnical Properties of Lime Stabilized Expansive Soil - Quarry Dust Mixes by Dr. Akshaya Kumar Sabat (SSN 2249-6149 Issue 2, Vol.1 (January -2012 Pg. No 42-49)

[2] R.K.Katti (1979) - Search for Solutions to Problems in Black Cotton Soils- IGC Annual Lecture, Indian Geotechnical Journal-Vol.9.

[3] Soil Mechanics And Foundation Engineering by Dr.K.Arora

[4] Soil Mechanics and Foundation Engineering By B.C.Punmina

[5] IS 2720 (Part 2)-1973, "Determination of Water Content".

[6] IS 2720 (Part 3/Sec 1)-1980, "Determination of Specific gravity".

[7] IS 2720 (Part 5)-1985, "Determination of Liquid Limit and plastic Limit". IS 2720 (Part 7)-1980,"Determination of Water Content-Dry Density Relation using Light Compaction".

[8] Katare R., Pande M.M., and Jain S.K. (2009) "Lime Stabilization Method of Black Cotton Soil" of Gwalior Region. ACSGE, BITS PILANI, India.

\section{Author Profile}

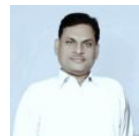

Brajesh Mishra received the B.E. and M. Tech degrees in Civil Engineering from Madan Mohan Malviya Engineering College, Gorakhpur, India (NowMMMUT) in 1988 and KNIT, Sultanpur, India in 2014 respectively. At present working with U.P. Cane Development Department, Lucknow, responsible for construction of road projects 